\title{
Optimization of a growth medium using a statistical approach for the production of an alkaline protease from a newly isolated Bacillus sp. L21
}

\author{
Canan Tari ${ }^{\mathrm{a}, *}$, Hande Genckal ${ }^{\mathrm{b}}$, Figen Tokatl ${ }^{\mathrm{a}}$ \\ ${ }^{a}$ Department of Food Engineering, Engineering Faculty, Izmir Institute of Technology, Gulbahce, Urla, Izmir 35430, Turkey \\ ${ }^{\mathrm{b}}$ Biotechology and Bioengineering Programme, Izmir Institute of Technology, Urla, Izmir 35430, Turkey \\ Received 2 June 2005; received in revised form 22 August 2005; accepted 23 August 2005
}

\begin{abstract}
Bacillus sp. L21 was isolated from the by-products of a leather factory (located in Izmir, Turkey) working under extreme alkaline conditions. Its phenotypic and genotypic identifications were completed, and determined as a potential alkaline protease producer. After screening various elements, carbon and nitrogen sources, soybean meal, maltose 50, tween 80 and the initial $\mathrm{pH}$ conditions were chosen as main factors to be used in the experimental design and response surface methodology (RSM) for the optimization of a low cost enzyme producing media for potential use on an industrial scale. The optimized values obtained by the statistical analysis showed that soybean meal at $3.0 \mathrm{~g} / \mathrm{l}$, maltose $50 \mathrm{between}$ the ranges of 30 and $40 \mathrm{~g} / \mathrm{l}$, tween 80 at $0.35 \mathrm{~g} / \mathrm{l}$ and an initial $\mathrm{pH}$ of 8.0 gives maximum protease activity.

(C) 2005 Elsevier Ltd. All rights reserved.
\end{abstract}

Keywords: Media optimization; Response surface method; Alkaline protease; Bacillus sp.; Low cost media

\section{Introduction}

Alkaline proteases are the main enzymes among the proteases which are known to constitute $60-65 \%$ of the global industrial market [1]. Most of them are used in the food industry in the meat tenderization process, peptide synthesis, for infant formula preparations, in baking and brewing. They are also used in the detergent industry as additives, in pharmaceuticals and medical diagnosis as well as in textile industry in the process of dehairing and leather processing [2]. Currently, a large proportion of the commercially available alkaline proteases are derived from Bacillus species because of their high $\mathrm{pH}$ and temperature stability [3,4]. It is reported that in the year 2005 the global proteolytic enzyme demand will increase dramatically to $1.0-1.2$ billon dollars [5]. Given the potential

\footnotetext{
is Significance of the work: This work proposes an optimized low cost industrial media formulation using response surface methodology, in the production of an alkaline protease from alkalophilic Bacillus sp. L21 which was newly isolated from leather by-products of a leather factory working under highly alkaline conditions, located in Izmir, Turkey with potential novel properties.

* Corresponding author. Tel.: +90 232 7506316; fax: +90 2327506196.

E-mail address: ctari7@yahoo.com (C. Tari).
}

uses of proteases and their high demand, the need exists for the discovery of new strains of bacteria that produce enzymes with novel properties and the development of low cost industrial media formulations. In this respect, the response surface method, which is used to study the effects of several factors influencing the responses by varying them simultaneously and carrying out a limited number of experiments [6], was thought to fit to the scope of this study. Optimization of media components by classical methods which involves the change of one variable at a time, is extremely time consuming and expensive when a large number of variables are considered. In order to overcome this difficulty and determine the interaction between the studied variables, an experimental factorial design and response surface method was employed for the optimization process. It is well documented that media components greatly influence the extracellular production of proteases in microorganisms and their interaction plays an important role in the synthesis of these enzymes [7]. Therefore, the objective of this study was to optimize the fermentation medium by applying response surface methodology for the production of an alkaline protease with possible novel characteristics. This enzyme was produced by Bacillus sp. L21, newly isolated from the by-products of a leather factory working under highly 
alkaline conditions that could be a potential candidate for industrial use.

\section{Material and methods}

\subsection{Organisms and culture condition}

Under the direction of the Department of Biology at IZTECH (Izmir Institute of Technology), Bacillus sp. L21 was isolated from the by-products of a leather factory. The phenotypic and genotypic study of this strain was completed and identified as a close homologue of Bacillus gibsonii and Bacillus pseudofirmus based on 16S-ITS rDNA RFPL analysis [8]. This organism showed higher proteolytic activity in the initial optimization study of the fermentation conditions as compared with the other two strains [9]. Therefore, taking this strain as a potential candidate for industrial use, a further detailed study on media optimization was proposed.

This microorgnism was cultivated in a solution containing $1 \%$ glucose, $0.5 \%$ yeast extract, $0.5 \%$ peptone, $0.1 \%$ potasium dihydrogen phosfate, $0.02 \%$ magnesium sulfate and $1 \%$ sodium carbonate where sterile sodium carbonate was added asseptically after the sterilization process. This formulation is known as the Horikoshi reference medium [10]. For the solid media preparation 1.5\% of agar was added to this formulation. The culture was regenerated every 2-3 weeks on a fresh plate from the frozen stock culture. All assays were performed using cell-free supernatant of the fermentation broth. The cell densities were determined by reading the optical densities at $600 \mathrm{~nm}$ and perfoming viable cell counts on the total broth. Biomass was also determined by drying the pellet after centrifugation (at $5000 \mathrm{rpm}$ for $10 \mathrm{~min}$ ) at $65^{\circ} \mathrm{C}$ for $24 \mathrm{~h}$ until it reached the equilibrium weight. The prescreening of the media components was done using the Horikoshi media as reference and changing the individual components one at a time. (This will be hereafter referred to as modified media.) The actual cultivation was carried out in $50 \mathrm{ml}$ of the modified media, inoculated with 5\% from the inoculum of the first subculture and incubated at $37^{\circ} \mathrm{C}$ and $180 \mathrm{rpm}$ for $70 \mathrm{~h}$ for the screening experiments and $88 \mathrm{~h}$ for the optimization study. The initial $\mathrm{pH}$ of this media was adjusted to 10.4 for screening experiments. The final $\mathrm{pH}$ dropped to around 9.1-9.5 which was still in the alkaline region. At certain time intervals samples were taken for the determination of cell density, protease activity, as well as total carbohydrate and protein contents.

\subsection{Assay for proteolytic activity}

Alkaline protease activity studies were done by applying a modified form of the method given by Takami et al. [10]. According to this procedure $0.250 \mathrm{ml}$ of Glycine: $\mathrm{NaCl}: \mathrm{NaOH}(50 \mathrm{mM}, \mathrm{pH} 10.5)$ buffer was incubated with $2.5 \mathrm{ml}$ of $0.6 \%$ casein dissolved in the same buffer at $30{ }^{\circ} \mathrm{C}$ until equilibrium was achieved. An aliquot of $0.25 \mathrm{ml}$ of the enzyme solution was added to this mixture and incubated for $20 \mathrm{~min}$. The reaction was stopped by adding $2.5 \mathrm{ml}$ TCA solution $(0.11 \mathrm{M}$ trichloroacetic acid, $0.22 \mathrm{M}$ sodium acetate and $0.33 \mathrm{M}$ acetic acid). After $10 \mathrm{~min}$ the entire mixture was centrifuged at $5000 \times \mathrm{g}$ for $15 \mathrm{~min}$. Supernatant in the amount of $0.5 \mathrm{ml}$ was mixed with $2.5 \mathrm{ml}$ of $0.5 \mathrm{M}$ $\mathrm{Na}_{2} \mathrm{CO}_{3}$ and $0.5 \mathrm{ml}$ of Folin-Ciocalteu's Phenol solution and kept for $30 \mathrm{~min}$ at room temperature. The optical density of the solutions were determined with respect to the sample blanks at $660 \mathrm{~nm}$. For these studies, one alkaline protease unit was defined as the enzyme amount that could produce $1 \mu \mathrm{g}$ of tyrosine in one minute under the defined assay conditions.

\subsection{Total protein content}

The total protein content of the samples were determined according to the method described by Lowry [11]; the protein standard used was bovine serum albumin. The results of the screening experiments were obtained from the average of two parallels.

\subsection{Total carbohydrate content}

Total carbohydrate content was determined according to the phenol-sulfuric acid method [12]. All the analytical grade materials were obtained from Sigma
(St Louis, USA). The industrial carbon and nitrogen sources were obtained from Cargill Sweetener and Starches Inc. and Cargill Soy Protein Solution Inc., respectively.

\subsection{Experimental design and statistical analysis}

In this study the effects of soybean meal, maltose 50 , tween 80 and initial $\mathrm{pH}$ on protease activity was evaluated using response surface methodology (RSM). A Box-Behnken design with four factors and central composite design (CCD) with two factors were used [13]. A total of 27 experiments in Box-Behnken in three blocks were performed for the media optimization part of the study. Block variables were three different incubator shakers to be able to run three different runs at the same time. An additional 12 media optimization experiments were designed in CCD. Analysis of data and generation of response surface graphics was done by Minitab statistical software (Release 13). The response variable in two sets of experiments was protease activity. After running the experiments and measuring the activity levels, a second order model including interactions was fitted to the protease activity data:

$Y=\beta_{0}+\sum_{i=1}^{k} \beta_{\mathrm{i}} X_{\mathrm{i}}+\sum_{i=1}^{k} \beta_{\mathrm{ii}} X_{\mathrm{i}}^{2}+\sum_{i} \sum_{j} \beta_{\mathrm{ij}} X_{\mathrm{i}} X_{\mathrm{j}}+\varepsilon$

where $Y$ is the predicted response, $k$ is the number of factor variables, $\beta_{0}$ is the model constant, $\beta_{\mathrm{i}}$ is the linear coefficient, $\beta_{\mathrm{ii}}$, is the quadratic coefficient, $\beta_{\mathrm{ij}}$, is the interaction coefficient. $X_{\mathrm{i}}$ is the factor variable in its coded form. The following equation was used for coding the actual experimental values of the factors in the range of $(-1$ to +1$)$ :

$X=\frac{[\text { actual }-(\text { low-level }+ \text { high-level }) / 2]}{(\text { high-level }- \text { low-level }) / 2}$

\section{Results and discussions}

\subsection{Screening of the media components}

\subsubsection{Effect of carbon sources}

In order to screen different industrial carbon sources, glucose $(40 \%)$, glucose syrup $(95 \%)$, fructose corn syrup (42\%), maltose50 (50\%, hereafter referred to maltose 50), glucose-fructose $(30 \%)$, natural corn starch, potato starch, molasses and whey were replaced at the same concentration $(10 \mathrm{~g} / \mathrm{l})$ with the carbon source (glucose) as indicated in the reference media. This complex media was inoculated and cultivated for $70 \mathrm{~h}$ at the fermentation conditions indicated in the materials and methods section of this paper, after which several conclusions were withdrawn. Except for whey, molasses and potato starch, the rest of the carbon sources gave satisfactory specific protease activity results (19.9$22.8 \mathrm{U} / \mathrm{mg}$ protein) compared to the control $(22.4 \mathrm{U} / \mathrm{mg}$ protein). The lowest specific activity was obtained with whey (8.5 U/mg protein) and highest with maltose $(22.8 \mathrm{U} / \mathrm{mg}$ protein). Similar results were obtained in the study of Mabrouk et al. [14] in the determination of the effect of various carbon sources on the proteolytic activity of Bacillus lichniformis ATCC 21415. However, if total protease enzyme activities are considered, glucose-fructose (30\%) and maltose50 can be considered as the best carbon sources of this study with total protease activities of 163.9 and $152.8 \mathrm{U} / \mathrm{ml}$, respectively. The activity for the control was determined as $152.4 \mathrm{U} / \mathrm{ml}$, where the rest of the carbon sources were below this value in the range of 73.6-139.2 U/ml. The overall product yield factor, $Y_{\mathrm{P} / \mathrm{S}}$, based on carbon source was calculated by neglecting 
endogenous metabolism and maintenance effects. Only potato starch showed a higher overall yield factor (40\% larger) as to the control, maltose 50 and corn starch; however, its specific and total proteolytic activities were lower. Considering all these factors and also due to its lower cost, maltose 50 was chosen as the best carbon source of these studies for further optimization study.

\subsubsection{Effect of nitrogen sources}

Casein (16\%), corn steep liquor $(50 \%)$, corn meal $(66 \%)$, soybean meal (fine), soybean (crude) (54\%) and whey (11.5\%) were screened as main nitrogen sources, by replacing the yeast extract at a concentration of $5 \mathrm{~g} / \mathrm{l}$ as indicated in the reference media. The percentages presented in the parenthesis are the percent total protein values as determined on a dry weight basis (w/w). This complex media was inoculated and cultivated for $70 \mathrm{~h}$ under the fermentation conditions mentioned in materials and methods section of this paper. According to the results, the lowest total protease activities in the amounts of 7.4, 28.4 and $49.9 \mathrm{U} / \mathrm{ml}$ and specific activities in the amounts of $0.46,3.4$ and $12.6 \mathrm{U} / \mathrm{mg}$ protein were obtained with casein, whey and corn meal, respectively. Better performance was seen for soybean meal (crude), yeast extract and corn steep liquor which showed protease activities of $102.5,114.9$ and $128.7 \mathrm{U} / \mathrm{ml}$, respectively. Their specific protease activities were also considerably higher (15.8, 29.8 and 36.1 U/mg protein) as compared to the other sources used. Since the scope of this study was to formulate low cost media, corn steep liquor and soybean meal (crude hereafter referred to soybean meal only), which are industrial byproducts of the corn and soybean industry were preferred over yeast extract due to its high cost. Even though corn steep liquor had the highest specific activity $(36.1 \mathrm{U} / \mathrm{mg}$ protein) when used alone, we decided to determine how its interaction with soybean meal influences enzyme activity, if presented together in the same media formulation. Resolution IV fractional factorial design with single replicate of treatment combinations of the four factors was employed. Design matrix of experiments and corresponding protease activity measurements are given in Table 1. In these experiments, the carbon source was taken as maltose 50 at a constant level of $10 \mathrm{~g} / \mathrm{l}$. According to these results, soybean meal or corn steep liquor could be used as a single nitrogen source, provided that tween 80 at $0.15 \mathrm{~g} / \mathrm{l}$ and

Table 1

$2_{\mathrm{IV}}^{4-1}$ fractional factorial design and protease activity results obtained with $5 \%$ of inoculum incubated at $37^{\circ} \mathrm{C}$ and $180 \mathrm{rpm}$ for $88 \mathrm{~h}$

\begin{tabular}{llllll}
\hline Run & \multicolumn{3}{l}{ Concentrations $(\mathrm{g} / \mathrm{l})$} & \multirow{2}{*}{ Protease activity (U/ml) } \\
\cline { 2 - 4 } & CSL & SoyB & Tween80 & $\mathrm{CaCl}_{2}$ & \\
\hline 1 & 5 & 5 & 0.35 & 0.5 & 148.7 \\
2 & 0.0 & 5 & 0.35 & 0.1 & 200.7 \\
3 & 5 & 5 & 0.15 & 0.1 & 108.5 \\
4 & 5 & 0.0 & 0.15 & 0.5 & 229.8 \\
5 & 5 & 0.0 & 0.35 & 0.1 & 194.1 \\
6 & 0.0 & 0.0 & 0.35 & 0.5 & 105.5 \\
7 & 0.0 & 5 & 0.15 & 0.5 & 238.4 \\
8 & 0.0 & 0.0 & 0.15 & 0.1 & 107.9 \\
\hline
\end{tabular}

CSL: corn steep liquor, SoyB: soybean meal.
$\mathrm{CaCl}_{2}$ at $0.5 \mathrm{~g} / \mathrm{l}$ are present in the same media formulation. (The detailed discussion on tween 80 and $\mathrm{CaCl}_{2}$ is given in the next section.) Soybean meal was used as the nitrogen source in the experimental design set up for response surface method, since it resulted in slightly higher activity than corn steep liquor. In the study of Fujiwara and Yamamoto [15], low cost nitrogen sources were screened for the alkaline protease production from Bacillus sp. The best result was attained when soybean meal together with Bonito extract was used as the main nitrogen source. In their study, soybean meal or corn steep liquor alone did not result in high activity. In the present study, peptone was used in addition to these components. Therefore, higher activity was expected.

\subsubsection{Effect of some elements and surfactant}

In order to study the effects of different elements on protease activity, the reference media was enriched with additions of

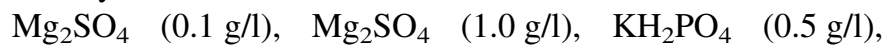
$\mathrm{KH}_{2} \mathrm{PO}_{4}(2.0 \mathrm{~g} / \mathrm{l}), \mathrm{CaCl}_{2}(0.1 \mathrm{~g} / \mathrm{l}), \mathrm{CaCl}_{2}(1.0 \mathrm{~g} / \mathrm{l})$ and tween 80 $(0.25 \mathrm{~g} / \mathrm{l})$ and cultivated for $70 \mathrm{~h}$ according to the procedure given in materials and method section. Tween 80 was used in these experiments in order to determine if it had a promoting or inhibiting effect on the enzyme synthesis. Tween80 is a well known industrial surfactant. Therefore, it was thought that its presence in the media would affect the homogeneity of the broth and facilitate the nutrient and oxygen transfer to the microorganisms. The decision on the concentrations of these components was based on literature data used for these types of fermentations $[1,16,17] . \mathrm{CaCl}_{2}$ at $0.1 \mathrm{~g} / \mathrm{l}$ and tween 80 at $0.25 \mathrm{~g} /$ 1 enhanced enzyme synthesis if used separately. These two components resulted in 12.66 and $18.7 \%$ more enzyme activity, respectively, as compared with the control. The positive effect of $\mathrm{CaCl}_{2}$ at $0.1 \mathrm{~g} / \mathrm{l}$ and tween 80 at $0.25 \mathrm{~g} / \mathrm{l}$ concentrations was pronounced with respect to specific protease activities (17.94 and $31.25 \%$ ) as well. The stimulating effect of $\mathrm{CaCl}_{2}$ was also reported by Mabrouk et al. [14] who explained this due to the stabilizing effect of $\mathrm{CaCl}_{2}$ on the alkaline protease. With this perspective in mind, $\mathrm{CaCl}_{2}$ was used in the fermentation media in order to stabilize the enzyme secreted into the fermentation broth and thus enhance its activity, if possible. This assumption proved to be true up to a certain concentration as discussed above. The higher $\mathrm{CaCl}_{2}$ concentration $(1 \mathrm{~g} / \mathrm{l})$ had an inhibitory effect resulting into an activity of $77.7 \mathrm{U} / \mathrm{ml}$ and specific activity of $8.7 \mathrm{U} / \mathrm{mg}$ protein, only. The presence of other components at the given concentrations did not influence the enzyme synthesis very much. It was difficult to decide which of the components, tween 80 or $\mathrm{CaCl}_{2}$, should be taken as a variable for the optimization process. Therefore, a preliminary study on their interaction when used together was performed. A fractional factorial design with the variables as corn steepliquor, soybean meal, tween 80 and $\mathrm{CaCl}_{2}$ were established and run at the same time. The decision on the concentration range used in this experiment was based on the results obtained from the screening experiments. From these results (Table 1) the presence of $\mathrm{CaCl}_{2}$ at $0.5 \mathrm{~g} / \mathrm{l}$ together with tween 80 at $0.15 \mathrm{~g} / \mathrm{l}$ regardless of the type of carbon source used, resulted in 1.5-1.6 times more protease activity when compared with the control. 
Therefore, according to the results of this preliminary study, $\mathrm{CaCl}_{2}$ at a concentration of $0.5 \mathrm{~g} / \mathrm{l}$ concentration was kept constant and tween 80 was used as one of the variables for the response surface analysis. The standard deviation of total and specific protease activity measurements for the screening experiments as performed in two parallels varied in range of 2$13 \mathrm{U} / \mathrm{ml}$ and $0.92-7.3 \mathrm{U} / \mathrm{mg}$ protein, respectively.

\subsection{Optimization by response surface methodology}

At the end of the screening experiments for different carbon, nitrogen sources, elements and surfactant, four factors were believed to play a significant role in protease activity; soybean meal as the nitrogen source, maltose 50 as the carbon source, tween 80 as the surfactant and initial $\mathrm{pH}$ of the fermentation medium. Peptone (5 g/l), $\mathrm{KH}_{2} \mathrm{PO}_{4}(1 \mathrm{~g} / \mathrm{l}), \mathrm{MgSO}_{4} \cdot 7 \mathrm{H}_{2} \mathrm{O}(0.2 \mathrm{~g} /$ 1) and $\mathrm{NaCO}_{3}(10 \mathrm{~g} / \mathrm{l})$ as indicated in the reference media were the constant components of this medium formulation. As explained, the $\mathrm{CaCl}_{2}$ concentration was fixed at $0.5 \mathrm{~g} / \mathrm{l}$. A BoxBehnken design with 27 experiments in three blocks was performed. The respective low and high levels $(\mathrm{g} / \mathrm{l})$ with the coded levels in parentheses for the factors were defined as 2.5 $(-1)$ and $7.5(+1)$ for soybean meal, $5(-1)$ and $15(+1)$ for maltose 50, $0.15(-1)$ and $0.35(+1)$ for tween $80,7(-1)$ and 12 $(+1)$ for the initial $\mathrm{pH}$. The experimental runs with their protease activity results are presented in Table 2. After

Table 2

Box-Behnken design and experimental results of protease activity obtained with $5 \%$ of inoculum incubated at $37^{\circ} \mathrm{C}$ and $180 \mathrm{rpm}$ for $88 \mathrm{~h}$

\begin{tabular}{lllrlcl}
\hline $\begin{array}{l}\text { Run } \\
\text { order }\end{array}$ & Blocks & $\begin{array}{l}\text { Soybean } \\
\text { meal }\end{array}$ & Maltose50 & Tween80 & pH & $\begin{array}{l}\text { Activity } \\
(\mathrm{U} / \mathrm{ml})\end{array}$ \\
\hline 1 & 2 & 5 & 5 & 0.25 & 12 & 151.6 \\
$2^{\mathrm{a}}$ & 2 & 5 & 10 & 0.25 & 9.5 & 160 \\
3 & 2 & 5 & 15 & 0.25 & 7 & 252.2 \\
4 & 2 & 5 & 5 & 0.25 & 7 & 192.8 \\
5 & 2 & 2.5 & 10 & 0.15 & 9.5 & 227 \\
6 & 2 & 7.5 & 10 & 0.15 & 9.5 & 226.5 \\
7 & 2 & 2.5 & 10 & 0.35 & 9.5 & 224.3 \\
8 & 2 & 5 & 15 & 0.25 & 12 & 158.7 \\
9 & 2 & 7.5 & 10 & 0.35 & 9.5 & 239.6 \\
10 & 3 & 7.5 & 10 & 0.25 & 7 & 126 \\
11 & 3 & 5 & 15 & 0.15 & 9.5 & 238.8 \\
12 & 3 & 5 & 5 & 0.15 & 9.5 & 178 \\
13 & 3 & 7.5 & 10 & 0.25 & 12 & 100.3 \\
$14^{\mathrm{a}}$ & 3 & 5 & 10 & 0.25 & 9.5 & 141 \\
15 & 3 & 2.5 & 10 & 0.25 & 7 & 182 \\
16 & 3 & 5 & 5 & 0.35 & 9.5 & 145.1 \\
17 & 3 & 5 & 15 & 0.35 & 9.5 & 211.4 \\
18 & 3 & 2.5 & 10 & 0.25 & 12 & 212.5 \\
19 & 1 & 5 & 10 & 0.35 & 12 & 128.5 \\
20 & 1 & 5 & 10 & 0.15 & 12 & 177 \\
21 & 1 & 5 & 10 & 0.35 & 7 & 230.1 \\
22 & 1 & 7.5 & 5 & 0.25 & 9.5 & 158.5 \\
23 & 1 & 2.5 & 15 & 0.25 & 9.5 & 268.2 \\
24 & 1 & 5 & 10 & 0.15 & 7 & 170.4 \\
25 & 1 & 2.5 & 5 & 0.25 & 9.5 & 194 \\
26 & 1 & 7.5 & 15 & 0.25 & 9.5 & 129.8 \\
$27^{\mathrm{a}}$ & 1 & 5 & 10 & 0.25 & 9.5 & 176.9 \\
\hline
\end{tabular}

a The standard deviation of activity measurements for the central runs is $17.9 \mathrm{U} / \mathrm{ml}$.
Table 3

Parameter estimates of model coefficients of 4-factor Box-Behnken design in coded units

\begin{tabular}{lc}
\hline Terms & Parameter estimates \\
\hline Constant & $159.3^{\mathrm{a}}$ \\
Block1 & -3.741 \\
Block2 & $18.404^{\mathrm{a}}$ \\
$X_{1}$ & $-27.275^{\mathrm{a}}$ \\
$X_{2}$ & $19.925^{\mathrm{a}}$ \\
$X_{3}$ & -3.225 \\
$X_{4}$ & $-18.742^{\mathrm{a}}$ \\
$X_{1}^{2}$ & 17.967 \\
$X_{2}^{2}$ & 16.767 \\
$X_{3}^{2}$ & $31.467^{\mathrm{a}}$ \\
$X_{4}^{2}$ & -7.858 \\
$X_{1} \times X_{2}$ & -25.725 \\
$X_{3} \times X_{4}$ & -27.05 \\
\hline
\end{tabular}

${ }^{\mathrm{a}} p$ value is less than 0.05 .

treatment combinations, the response data for soybean meal and maltose 50 concentrations, $\mathrm{pH}$, and the quadratic term of tween80 yielded significant terms (Table 3 ). All the quadratic terms were also included in the model since the removal of these terms caused a decrease in the adjusted $R^{2}$ term of the model. It was concluded that among the six interaction terms only those of soybean meal and maltose50 $\left(X_{1} \times X_{2}\right)$ and of tween 80 and $\mathrm{pH}\left(X_{3} \times X_{4}\right)$ were considered significant since their $p$-values were slightly higher than 0.05 ( $p$-values for the $\left(X_{1} \times X_{2}\right)$ term was 0.107 , whereas the $p$-value for $\left(X_{3} \times X_{4}\right)$ was 0.092). Other interaction terms were neglected. The final empirical model for protease activity in terms of four factors in coded units was as follows:

$$
\begin{aligned}
Y= & 159.3+18.404-27.275 X_{1}+19.925 X_{2}-3.225 X_{3} \\
& -18.742 X_{4}+17.967 X_{1}^{2}+16.767 X_{2}^{2}+31.467 X_{3}^{2} \\
& -7.858 X_{4}^{2}-25.725 X_{1} X_{2}-27.05 X_{3} X_{4}
\end{aligned}
$$

According to the response surface graphic of $X_{1}$ and $X_{2}$ (Fig. 1), maximum activity can be achieved at low values of soybean meal and high values of maltose 50. Also, it was seen that initial $\mathrm{pH}$ values close to neutral have a positive effect on

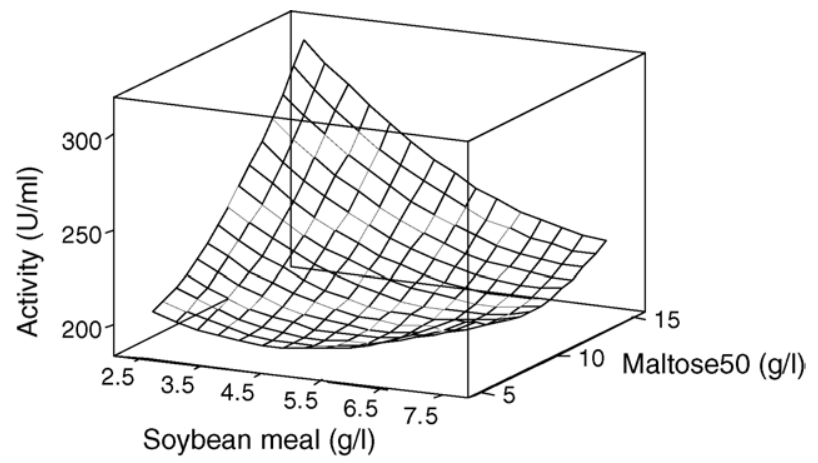

Hold values: Tween80: $0.35 \mathrm{~g} / \mathrm{l} \quad \mathrm{pH}: 8.5$

Fig. 1. Response surface curve of protease activity affected by soybean meal and maltose 50 concentrations at constant values of tween 80 at $0.35 \mathrm{~g} / 1$ and an initial $\mathrm{pH}$ of 8.5 using the 4-factor Box Behnken design. 


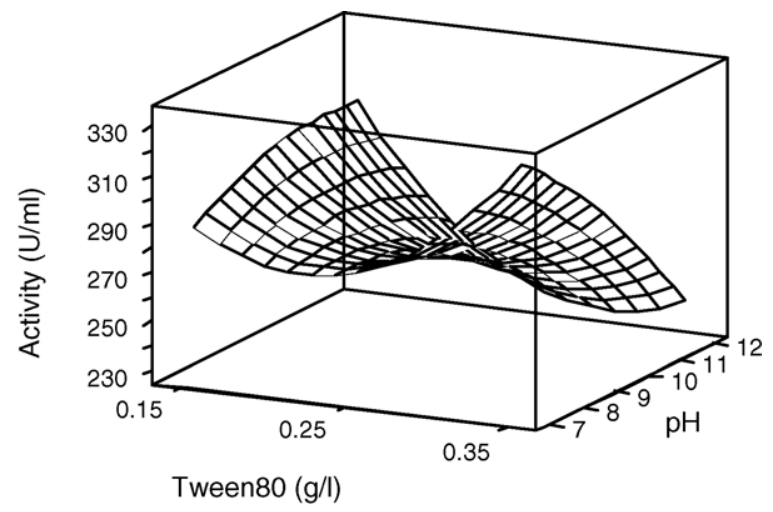

Hold values: Soybean meal: $2.5 \mathrm{~g} / \mathrm{l} \quad$ Maltose $50: 15 \mathrm{~g} / \mathrm{l}$

Fig. 2. Response surface curve of protease activity affected by tween 80 concentrations and initial $\mathrm{pH}$ at constant values of soybean meal at $2.5 \mathrm{~g} / 1$ and maltose50 at $15 \mathrm{~g} / \mathrm{l}$ using the 4-factor Box Behnken design.

activity (Fig. 2). At these conditions if one keeps the tween 80 around its maximum level, there is an increase in protease activity. For this reason, in order to achieve the maximum enzyme activity, the $\mathrm{pH}$ and tween 80 were kept constant at 8.5 and $0.35 \mathrm{~g} / \mathrm{l}$, respectively (Fig. 1). Similarly in Fig. 2, soybean meal and maltose50 were kept constant at 2.5 and $15 \mathrm{~g} / \mathrm{l}$, respectively. To validate this model, experiments at $2.5 \mathrm{~g} / \mathrm{l}$ soybean meal, 12 and $15 \mathrm{~g} / 1$ maltose $50,0.35 \mathrm{~g} / 1$ tween 80 and initial $\mathrm{pH}$ ranging from 7.0 to 9.5 were performed and the enzyme activity values were measured. At the end of each experiment the final $\mathrm{pH}$ of the fermentation medium was recorded and it was determined that $\mathrm{pH}$ settled at 9.2. The maximum protease activity was found to be $294 \mathrm{U} / \mathrm{ml}$, using $2.5 \mathrm{~g} / 1$ soybean meal, $15 \mathrm{~g} / 1$ maltose 50 , and $0.35 \mathrm{~g} / \mathrm{l}$ tween 80 at an initial $\mathrm{pH}$ of 8.5 , where the model predicted a value of $338 \mathrm{U} / \mathrm{ml}$, under the same conditions. However, true optimum values for the significant factors could not be determined because of the saddle nature of the response surfaces (Figs. 1 and 2). Therefore, it was decided to conduct a 2 -factor central composite design (CCD) at constant $\mathrm{pH}$ of 8 and $0.35 \mathrm{~g} / \mathrm{l}$ of tween80, where maltose 50 was present at concentrations of 12 , 20 and $28 \mathrm{~g} / \mathrm{l}$ and soybean meal at 0,2 and $4 \mathrm{~g} / \mathrm{l}$. These variables were taken as the main factors. The reason why these two factors (maltose50, soybean meal) were chosen and the others (pH and tween80) were kept constant, was their economical significance in industrial processes. The protease activity results of the CCD of 12 different runs are presented in Table 4 . At the end of the analysis of response data and treatment combinations, it was concluded that the quadratic term of maltose50 and the interaction term were neglected. All the linear terms and the quadratic term of soybean meal were included in the model since these were the significant terms based on $p<0.01$. The final empirical model for protease activity using the least square estimate of parameters, $\beta_{\mathrm{i}}$, in terms of two factors in coded units is described as shown in Eq. (4).

$Y=284.68+83.77 X_{1}+12.72 X_{2}-92.32 X_{1}^{2}$
Table 4

Central composite design and experimental results of protease activity obtained with $5 \%$ of inoculum incubated at $37^{\circ} \mathrm{C}$ and $180 \mathrm{rpm}$ for $88 \mathrm{~h}$

\begin{tabular}{clll}
\hline Run order & Soybean meal $(\mathrm{g} / \mathrm{l})$ & Maltose50 $(\mathrm{g} / \mathrm{l})$ & Activity $(\mathrm{U} / \mathrm{ml})$ \\
\hline $1^{\mathrm{a}}$ & 2 & 20 & 293.5 \\
$2^{\mathrm{a}}$ & 2 & 20 & 306.5 \\
3 & 4 & 12 & 273.8 \\
4 & 4 & 28 & 297.9 \\
$5^{\mathrm{a}}$ & 2 & 20 & 284.7 \\
61 & 0 & 28 & 149.2 \\
7 & 2 & 12 & 280.9 \\
8 & 0 & 12 & 80.6 \\
$9^{\mathrm{a}}$ & 2 & 20 & 278.0 \\
10 & 4 & 20 & 256.7 \\
11 & 2 & 28 & 264.5 \\
12 & 0 & 20 & 96.0 \\
\hline
\end{tabular}

${ }^{a}$ The standard deviation of activity measurements for the central runs is $12.3 \mathrm{U} / \mathrm{ml}$.

The adjusted $R^{2}$ of the model was $93.3 \%$ with an insignificant lack of fit ( $p$ value $=0.141)$. According to Fig. 3 and the first derivative of $Y$ with respect to $X_{1}$, maximum activity could be achieved at $3.0 \mathrm{~g} / \mathrm{l}$ of soybean meal. Since no optimum maltose50 concentration could be determined, additional experiments at $3.0 \mathrm{~g} / \mathrm{l}$ of soybean meal, $0.35 \mathrm{~g} / \mathrm{l}$ of tween 80 and at a $\mathrm{pH}$ of 8 were conducted at different maltose 50 concentrations, namely 20, 30, 40, 50, 60, and $80 \mathrm{~g} / \mathrm{l}$. Measurements of the activity levels for these concentrations were determined as $251.4,269.3,254.0,224.2$ and $215.8 \mathrm{U} / \mathrm{ml}$, respectively. Based on this, an optimum concentration of maltose 50 could be achieved between the ranges of 30 and $40 \mathrm{~g} / \mathrm{l}$. The maximum activity under these conditions was determined as $269 \mathrm{U}$ activity $\mathrm{ml}^{-1}$. It was thought that these newly optimized conditions would even enhance the activity, compared to the previous activity data of $294 \mathrm{U} / \mathrm{ml}$ obtained in the validation experiments of the Box-Behnken design. This decreasing trend in the activity values can be explained by some unknown factors resulting possibly from strain instability and experimental errors.

On the other hand, comparison of response results of BoxBehnken design and CCD shows that protease activity values were higher in the second set of experiments (Tables 2 and 4). In $\mathrm{CCD}$, media composition and $\mathrm{pH}$ were adjusted according to

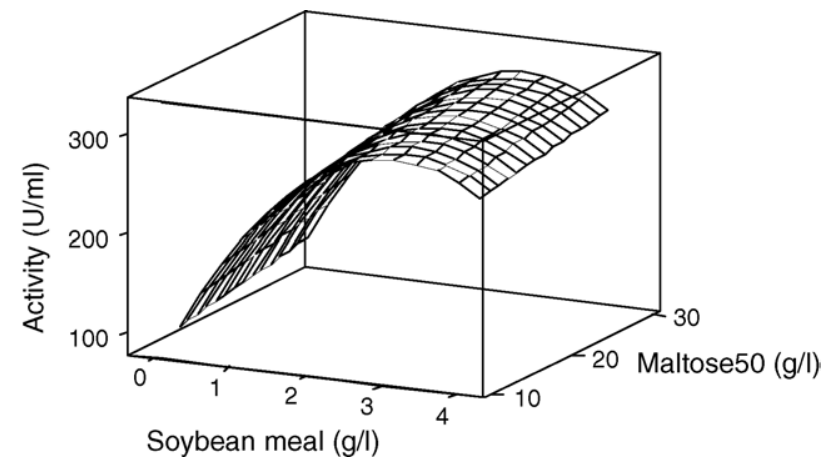

Fig. 3. Response surface curve of protease activity affected by soybean meal and maltose50 concentrations using the 2-factor central composite design. 
the first set of experiments (Box-Behnken design) to be able to get an optimum set of parameters for better protease activity. For example, the maximum activity value of $268.2 \mathrm{U} / \mathrm{ml}$ in the Box Behnken design was achieved at $2.5 \mathrm{~g} / 1$ soybean meal, $15 \mathrm{~g} / \mathrm{l}$ maltose $50,0.25 \mathrm{~g} / \mathrm{l}$ tween 80 and at an initial $\mathrm{pH}$ of 9.5 . The closest composition to this combination in the second set $(\mathrm{CCD})$ is $2 \mathrm{~g} / \mathrm{l}$ soybean meal, $20 \mathrm{~g} / 1$ maltose $50,0.35 \mathrm{~g} / \mathrm{l}$ tween 80 and initial $\mathrm{pH}$ of 8 , which produced activity values in the range of $278-306.5 \mathrm{U} / \mathrm{ml}$. This adjustment caused an increasing trend in the overall activity results.

There have been a number of studies conducted on optimization of different physicochemical parameters of different organisms using response surface methodology [18-21]. In general there is no defined medium designed for the production of alkaline protease from different microbial sources $[18,22,23]$. Every organism is unique in its requirement for the mentioned parameters for maximum enzyme production. Therefore, each of them has to be considered separately and the requirements have to be optimized accordingly. Among some of the examples is the recent study done by Chauhan and Gupta [18] on Bacillus sp. RGR-14 for alkaline protease production, where they determined a 12.85 fold increase by optimizing starch, casamino acid, phosphate ion and inoculum concentrations using the response surface method. Another study performed by Beg et al. [20] showed that alkaline protease production produced by Bacillus mojavensis was improved up to 4.2 fold in a bioreactor of 141 using response surface method. Optimization of growth medium for the production of spores from Bacillus thuringies using response surface methodology conducted by Lui and Tzeng [24] demonstrated the major effect of the media ingredients on the final spore count. All these and number of other studies $[6,7,23,25]$ clearly show that this technique is very powerful in the optimization of bioprocesses. Using cost effective media formulation and optimizing it at its minimum requirements for maximum enzyme production is extremely important in industrial scale for economic reasons. Therefore, using common industrial ingredients such as soybean meal, maltose50 and tween80, which are known for their low cost and then optimizing the process using response surface methodology will serve as a potential example for the applications used in industrial microbial fermentations.

\section{Conclusion}

It is highly important to discover new bacterial-strains that produce enzymes with novel properties that could be of industrial value [9]. Using response surface methodology, a low cost media formulation for alkaline protease production from the newly isolated Bacillus sp. L21 was developed as a result of screening various low cost industrial carbon, nitrogen sources, elements and a surfactant. Results show that soybean meal as the nitrogen source, maltose 50 as the carbon source, tween 80 and initial $\mathrm{pH}$ were determined to be used as the main variables in the response surface analysis. The optimum region of protease activity was found at $3.0 \mathrm{~g} / \mathrm{l}$ of soybean meal, maltose 50 concentration of $30-40 \mathrm{~g} / 1,0.35 \mathrm{~g} / \mathrm{l}$ of tween 80 and an initial $\mathrm{pH}$ of 8 . The maximized activity $(306.5 \mathrm{U} / \mathrm{ml})$ was low when compared with the protease activity of many Bacillus sp. used industrially; although it should be taken into account that those activities were obtained from purified enzymes. Here the activity was obtained from the crude enzyme, obtained from a strain which did not go through any strain improvement step. After further optimization is carried out using optimized medium for batch and fed batch systems and after optimizing the fermentation parameters (aeration, agitation speed, dilution rate, inoculation ratio etc.), the enzyme activity is expected to increase. In this regard, this paper proposes a low cost medium formulation that could be of industrial value and could serve as a basal media for further optimization studies of this and similar strains. Furthermore, this study serves as another example for the application of the response surface methodology to biological systems and it introduces a new Bacillus sp. L21 strain as a potential candidate for the alkaline protease production that could have novel properties of industrial value.

\section{Acknowledgements}

Financial support of Izmir Institute of Technology and the kind supply of the strains by the Department of Biology at Izmir Institute of Technology are gratefully acknowledged.

\section{References}

[1] Banerji CU, Sani RK, Azmi W, Soni R. Thermostable alkaline protease from Bacillus brevis and its characterization as a laundry detergent additive. Process Biochem 1999;35:213-9.

[2] Joo HS, Kumar GC, Park GC, Paik SR, Chang CS. Oxidant and SDS stable alkaline protease from Bacillus clausii I-52: production and some properties. J Appl Microbiol 2003;95:267-72.

[3] Gupta R, Beg QK, Lorenz P. Bacterial alkaline proteases: molecular approaches and industrial applications. Appl Microbiol Biot 2002; $1-31$.

[4] Joo HS, Kumar GC, Park GC, Kim TK, Paik SR, Chang CS. Optimization of the production of an extra cellular alkaline protease from Bacillus horikoshii. Process Biochem 2002;38:155-9.

[5] Godfrey T, West S. Introduction to industrial enzymology. Industrial enzymology, 2nd ed., New York: Stocholm Press, 1996. pp. 1-7.

[6] Adinarayana K, Ellaiah P. Response surface optimization of the critical medium components for the production of alkaline protease by a newly isolated Bacillus sp.. J Pharm Sci 2002;5:272-6.

[7] Puri S, Khali O. Gupta R Optimization of alkaline protease production from Bacillus sp. By response surface methodology. Curr Microbiol 2002; 44:286-90.

[8] Akbalik G, Günes H, Yavuz E, Yasa I, Harsa S, Elmacı SZ, et al. Identification of extracellular enzyme producing alkalophilic bacilli from Izmir province by 16S-ITS rDNA RFLP. J Appl Microbiol 2004; 766-73.

[9] Genckal H, Tari C. Alkaline protease production from alkaliphilic Bacillus sp. isolated from natural habitats (submitted to Enzyme Microb Tech 2005: reference number 2005118/1).

[10] Takami H, Akiba T, Horikaoshi K. Production of extremely thermostable alkaline protease from Bacillus sp. No. AH-101. Appl Microbial Biot 1989;30:120-4.

[11] Lowry OH, Rosebrough NJ, Farr AL, Randall JR. Protein measurement with the folin phenol reagent. J Biol Chem 1951;193:265-75.

[12] DuBois M. Colorimetric method for determination of sugars and related substances. Anal Chem 1956;28:350-6.

[13] Montgomery D. Design and analysis of experiments, 5th ed., New York: Wiley, 2001. 
[14] Mabrouk SS, Hashem AM, El-Shayeb NMA. Ismail MS, Abdel-Fattah AF. Optimization of alkaline protease productivity by Bacillus licheniformis ATCC 21415. Bioresource Technol 1999;69:155-9.

[15] Fujiwara N, Yamamoto K. Production of alkaline protease in low cost medium by alkalophilic Bacillus sp. and properties of the enzyme. J Fermentation Technol 1987;65:345-8.

[16] Ellouz Y, Bayoudh S, Kammoun N, Gharsallah N, Nasri M. Production of protease by Bacillus substilis grown on sardinelle heads and viscera flour. Bioresource Technol 2001;80:49-51.

[17] Johnvesly B, Naik GR. Studies on production of thermostable alkaline protease from thermophilic and alkaliphilic Bacillus sp. JB-99 in a chemically defined medium. Process Biochem 2001;37:139-44.

[18] Chauhan B, Gupta R. Application of statistical experimental design for optimization of alkaline protease production from Bacillus sp. RGR-14. Process Biochem 2004;39:2115-22.

[19] Rahman AR, Illias MdR, Nawawi MGM, Ismail AF, Hassan O, Kamaraduddin K. Optimization of growth medium for the production of cyclodextrin glucanotransferease from Bacillus stearothermophilus HR1 using response surface methodology. Process Biochem 2004;39:2053-60.
[20] Beg QK, Sahai V, Gupta R. Statistical media optimization and alkaline protease production from Bacillus mojavensis in a bioreactor. Process Biochem 2003;39:203-9.

[21] Lui HL, Lan YM, Cheng YC. Optimal production of sulfuric acid by Thiobacillus thiooxidans using response surface methodology. Process Biochem 2004;39:1953-61.

[22] Li C, Bai J, Cai Z, Ouyang F. Optimization of a cultural medium for bacteriocin production by Lactococcus lactis using response surface methodology. J Biotechnol 2002;93:27-34.

[23] Ramirez R, Gutierrez H, Gschaedler A. Optimization of astaxantin production by Phaffia rhodozyma through factorial design and response surface methodology. J Biotechnol 2001;88:259-68.

[24] Lui BL, Tzeng YM. Optimization of growth medium for the production of spores from Bacillus thuringiensis using response surface methodology. Bioproc Eng 1998;18:413-8.

[25] Rodrigues DC, Silva SS, Felipe MGA. Using response surface methodology to evaluate xylitol production by Candida guilliermondii by fed-batch process with exponential feeding rate. J Biotechnol 1998; 62:73-7. 